\title{
VÝZKUM POZDNĚ KVARTÉRNÍ AKTIVITY ZLOMU KOSÍŘE V HORNOMORAVSKÉM ÚVALU ANEB PROČ JE DOBRÉ STUDOVAT SVAHOVINY A SEISMOGRAMY
}

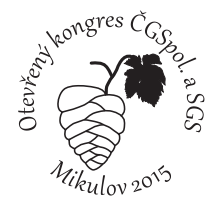

\author{
Late Quaternary slip at the Kosír Fault of the Upper Morava Basin - an example \\ of joint research using trenching and microseismic monitoring
}

\author{
Petr Špaček, Vít Ambrož \\ Ústav fyziky Země PřF MU, Tvrdého 12, 60200 Brno; e-mail: spacek@ipe.muni.cz
}

(24-24 Prostějov, 24-22 Olomouc)

Key words: Upper Morava Basin, Kosír Fault, active faulting, paleoseismology, Quaternary

\begin{abstract}
Preliminary results of a research into the late Quaternary slip of a major fault in the seismically active Upper Morava Basin are given. Three trenches, up to $6 \mathrm{~m}$ deep, were excavated at the foot of the Kosír Fault scarp near Starechovice and Čelechovice. The exposed complex sequences of colluvium and loess, now only partly dated by OSL and ${ }^{14} \mathrm{C}$, is heavily faulted. The faulting is explained by a tectonic slip at the Kosir Fault and, in the Starechovice trench, also by simultaneous slope deformations. None of the faults do offset the Holocene topsoil but the youngest of them were clearly active after the deposition of the youngest loess and indicate the slip of up to $1.4 \mathrm{~m}$ in Late Pleistocene. In Čelechovice trenches the minimum vertical throw of $4 \mathrm{~m}$ is indicated for the lower part of the sequence with assumed Late Pleistocene age. The geometry of the deformed zone suggests an oblique normal faulting with significant strike-slip component. The sense of shearing in the horizontal plane was not resolved. Minimum tectonic slip rate of 0.1-0.3 mm/ year in Late Pleistocene is suggested but this must be confirmed by new dating. Our observations reveal surprisingly young and large deformation which may suggest a temporary increase of tectonic activity during Late Pleistocene.
\end{abstract}

\section{Úvod}

Tektonická aktivita většiny zlomů v Českém masivu v období kvartéru není dobře prostudována. Hlavním důvodem deficitu podrobnějších informací na toto téma je obtížnost výzkumu pohybů na „pomalých“ zlomech v oblasti opakovaně zasažené periglaciálními procesy při současném nedostatku akumulace sedimentů ve vyhovujících prostředích. Studie, které kvartérní pohyby na zlomech řeší detailně, se objevují teprve v posledních letech v rámci základního výzkumu či jako součást výzkumu aplikovaného na problematiku bezpečnosti jaderných elektráren, prováděného Ústavem fyziky Země MU (ÚFZ), Ústavem struktury a mechaniky hornin AVČR a spolupracujícími odborníky. Takové studie byly nebo jsou prováděny na sudetském okrajovém zlomu v Rychlebských horách (Štěpančíková et al. 2010), hlubockém zlomu v budějovické pánvi (Špaček et al. 2011), okrajovém zlomu chebské pánve (Štěpančíková et al. 2015), na zlomech v Hornomoravském úvalu (viz níže) a v severní části diendorfského zlomu u Miroslavi (Špaček et al. 2015, nepublikováno).

Důležitou součástí tohoto výzkumu je aplikování souboru metod, který využívá obor paleoseismologie. Postup zahrnuje zjištění přesné pozice zlomu a základní charakteristiky pokryvných sedimentů pomocí geofyzikálních metod, odkrytí akumulací sedimentů nad zlomem kopanými rýhami v blízkosti paty zlomového svahu, detailní studium stratigrafických poměrů a deformačního porušení těchto sedimentů, datování sedimentů a komplexní interpretace. Vzhledem k často složitým kombinacím sedimentačních i deformačních procesů ve specifickém prostředí zlomového svahu je vhodné provádět interpretaci na podkladu širokého spektra od- borných pohledů specialistů v oborech kvartérní geologie, sedimentologie a strukturní geologie.

Zcela odlišným, ale neméně důležitým pohledem na problematiku pohybů na zlomech je studium mikroseismické aktivity, která indikuje pokračující uvolňování napětí křehkými rupturami ve svrchní zemské kůře a může naznačovat existenci zlomů, které jsou aktivní i v současnosti. Ve východní části České republiky je seismicita monitorována 14 seismologickými stanicemi ÚFZ (viz www.ipe.muni.cz) a několika stanicemi spolupracujících institucí.

Níže uvedený příklad základního výzkumu aktivity zlomů řešeného v současnosti v oblasti Hornomoravského úvalu ilustruje způsob metodického řešení a možné výstupy takovéhoto kombinovaného postupu.

\section{Hornomoravský úval - stále aktivní pánev?}

Jednou ze studovaných oblastí, kde je zvýšená míra aktivity zlomů v období kvartéru indikována geologickou stavbou i probíhající seismickou aktivitou, je Hornomoravský úval (HMÚ). HMÚ je komplexní systém plio-pleistocenních pánví založený na sz.-jv. zlomové struktuře (zlomové pásmo Hané) a superponovaný na alpínský styk Českého masívu a vnějších Karpat. V nadloží hlavního plio-pleistocenního souvrství a pod středno- a svrchnopleistocenními terasami je lokálně vyvinuta až $60 \mathrm{~m}$ mocná akumulace fluviálních až fluviolakustrinních klastických sedimentů pravděpodobně střednopleistocenního stáří (Macoun - Růžička 1967; Růžička 1973), která indikuje pokračování subsidence během kvartéru přinejmenším v lokálním měřítku. Ačkoli pro aktivitu zlomů v období svrchního pleistocénu nemáme mnoho indikací, bezmála dvacetiletý seismologický monitoring ukazuje, 


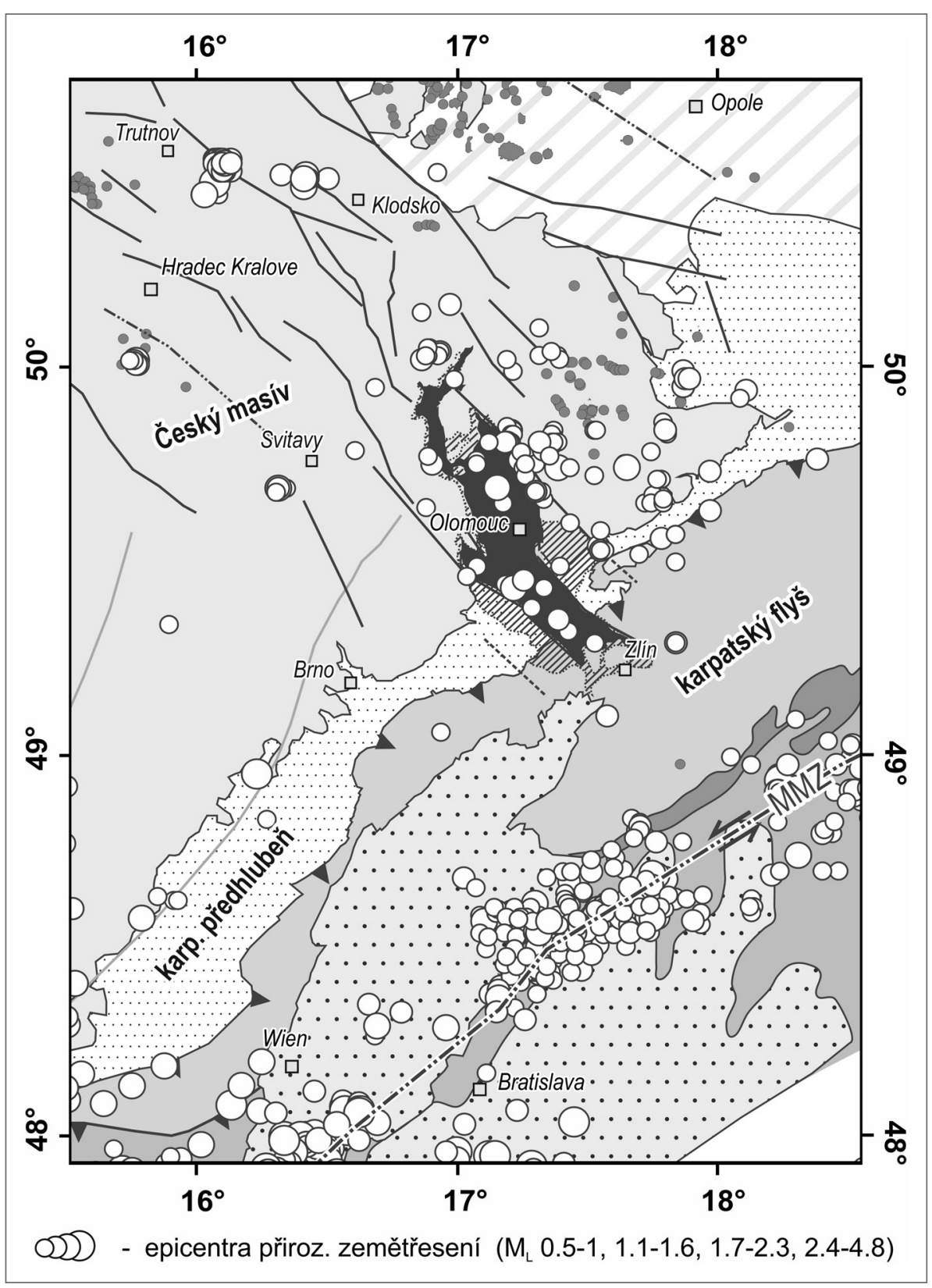

Obr. 1: Schematická mapa oblasti styku Alp, Karpat a Českého masivu s vyznačením pozice Hornomoravského úvalu a současné seismicity. Rozsah významných akumulací plio-pleistocenních sedimentů je označen černou barvou. Šrafovaně je označen rozsah reliktních výskytů sedimentů. Epicentra zemětřesení jsou označena bílými kolečky (katalog IPE2009: jevy z let 2000-2009 s lokálním magnitudem $M L \geq 0,5)$. Šedá kolečka ukazují výskyty neovulkanitů. $M M Z$ - zóna Mur-Mürz-Leitha (např. Lenhardt et al. 2007).

Fig. 1: Schematic map showing the position of the Upper Morava Basin System and current seismicity in the Alpine-Carpathian-Bohemian Massif junction region. The extent of major accumulations of Plio-Pleistocene sediments in the basin is indicated by black colour; hatching indicates the extent of relict sediments. Earthquake epicentres (white circles) are from IPE2009

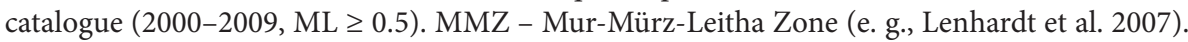
Grey circles indicate the occurrences of Cenozoic volcanic rocks.

že HMÚ je součástí oblasti s regionálně anomální mírou recentní mikroseismické aktivity, jejíž geografický rozsah je přibližně vymezen spojnicí měst Trutnov, Svitavy, Zlín, Ostrava a Kłodsko (tzv. zóna Nysa-Morava; např. Špaček et al. 2015a; obr. 1). Seismicky aktivní oblast nápadně koreluje s oblastí zvýšené migrace $\mathrm{CO}_{2}$, která zřejmě primárně souvisí s doznívající magmatickou aktivitou $\mathrm{v}$ litosféře, ale pravděpodobně odráží i specifický stav napjatosti ve svrchní kůře. To je podpořeno i zjištěnými ohniskovými mechanismy několika mikrozemětřesení, které indikují poklesy a pravostranné horizontální posuny na sz.-jv. až s.-j. orientovaných zlomech a tedy možnou lokální rotaci směru maximální komprese do subvertikální polohy a extenzní/transtenzní režim (Špaček et al. 2015a). Jihozápadní omezení seismicky aktivní oblasti je poměrně velmi ostré a v regionálním měřítku koinciduje se zlomovou zónou Nectava-Konice-Kvasice.

\section{Výzkum zlomu Kosíře}

$\mathrm{V}$ rámci probíhajícího výzkumu byl po regionálním průzkumu vybrán a detailně studován zlom, tvořící jihozápadní omezení elevace Velkého Kosíře (dosud bezejmenný zlom bude nadále označován jako zlom Kosíře). Tento sz.-jv. orientovaný zlom, omezující terciérní sedimenty prostějovského výběžku HMÚ, má výrazné morfologické projevy v délce $>20 \mathrm{~km}$ (obr. 2). Elektrická odporová tomografie v okolí Stařechovic a Čelechovic (předběžně např. Špaček et al. 2015b) a nově provedený mělký vrt u Stařechovic ukazují omezení pánve zlomem stř̀edně až strmě $\left(50-80^{\circ}\right)$ ukloněným $\mathrm{kJZ}$ a prrítomnost až 20 m mocných akumulací kvartérních sedimentů v pánevní části svahu přímo pod stopou zlomu.

$\mathrm{Na}$ dvou vybraných lokalitách na zlomu (obr. 2) byly v průběhu let 2013-2015 otevřeny tři kopané rýhy délky až $30 \mathrm{~m}$ a hloubky 4-6m. $\mathrm{V}$ rýhách byly odkryty profily sekvencí různých typů svahovin, sprašovými hlínami se splachovými písky a štěrčíky, sprašemi a holocenním půdním horizontem. Ve svrchní části profilů vystupují v podloží této sekvence paleozoické sedimenty, zatímco v nižší části (v pokleslém bloku) nebylo podloží dosaženo (obr. 3). 


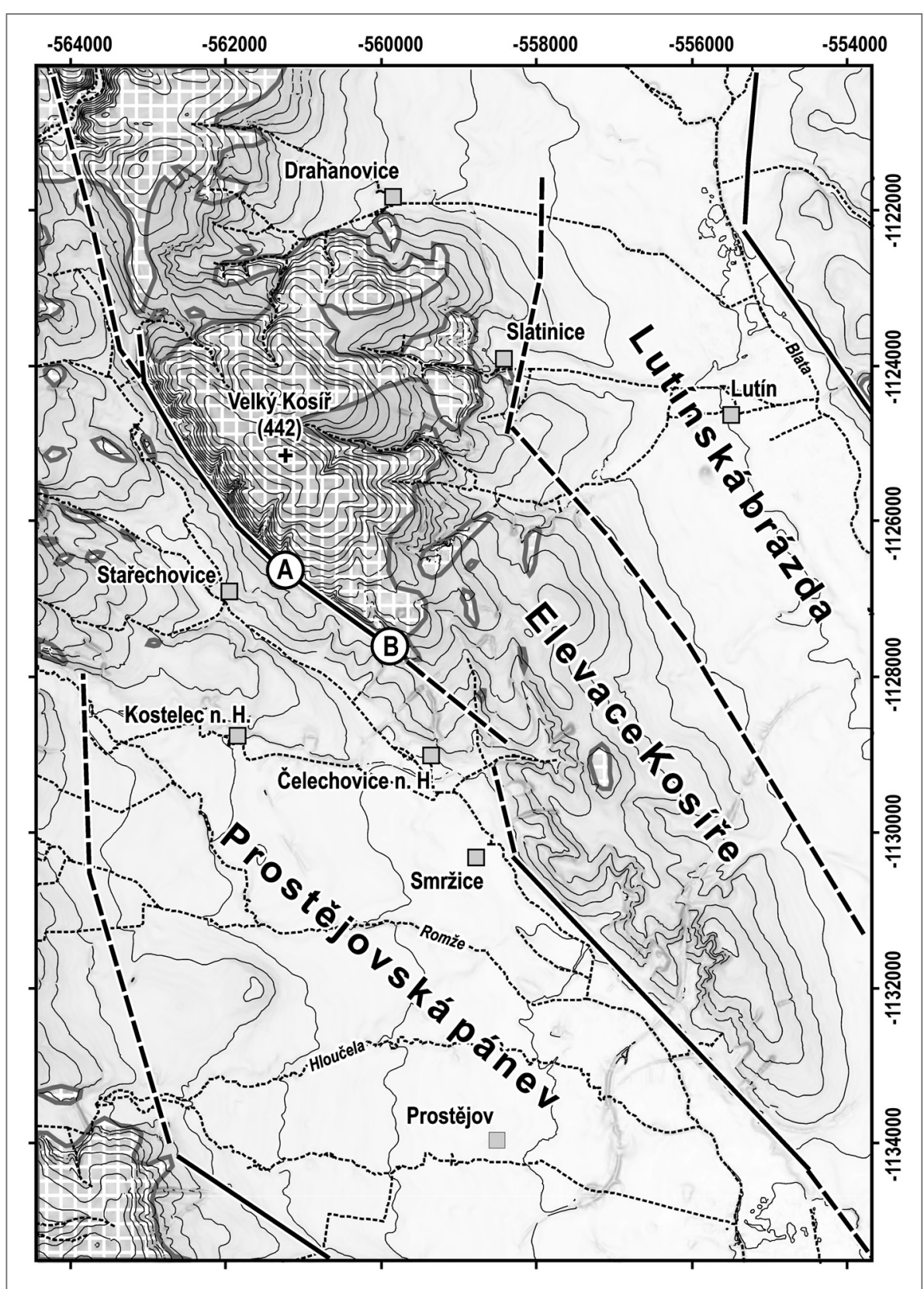

Obr. 2: Schematická mapa oblasti elevace Kosíŕe s pozicí studovaného zlomu a lokalit výzkumu v kopaných rýhách. A - Rýha Stařechovice; B - rýhy Čelechovice 1 a 2.

Fig. 2: Schematic map showing the Kosír elevation within the Upper Morava Basin, the position of the fault studied and the two trenching sites: A - trench Stařechovice; B - trenches Čelechovice 1 and 2 .

\section{Rýha Stařechovice}

V první rýze na lokalitě Stařechovice $\left(49,5347^{\circ} \mathrm{N}\right.$; $\left.17,0637^{\circ} \mathrm{E}\right)$ je odkrytá sukcese sedimentů porušena systémem strmých $\left(60-80^{\circ}\right)$ zlomů s úklonem k JZ (obr. 3 a 4) a podružných antitetických zlomů. Charakter zlomů a porušení stratigrafie indikuje dominanci poklesové složky pohybu, přičemž pohyb na zlomech byl současný s různými fázemi akumulace sedimentů a aktivita zlomů progradovala směrem $\mathrm{z}$ pánve do svahu elevace. Vertikální složka posunu v odkrytých částech zlomů kolísá v rozmezí od $<1 \mathrm{~cm}$ do $1,6 \mathrm{~m}$. Podrobné datování sedimentů založené na šesti OSL a jednom 14C-AMS datu (provedeno v laboratořích Univerzity Gliwice; obr. 3) ukazuje stáří 75-12 tis. let BP a umožňuje časově šká- lovanou rekonstrukci sedimentačních a deformačních procesů. Hlavní, nejmladší zlom vykazuje relativně vysokou průmèrnou rychlost posunu $0,2-0,3 \mathrm{~mm} / \mathrm{rok}$ v období 17-11 tis. let BP. Charakter některých zlomů v této rýze (množství slepých zlomů, které nepokračují do předkvartérního podloží) indikuje kombinaci tektonických pohybů na aktivním zlomu a s nimi současných svahových pohybů, přičemž tyto dvě složky je obtížné rozlišit. Je třeba zdůraznit, že zjištěná rychlost posunu na zlomech v malém měřítku by $\mathrm{z}$ těchto důvodů neměla být přímo ztotožňována $s$ rychlostí tektonického pohybu na zlomech ve velkém měřítku.

\section{Rýhy Čelechovice}

Druhá lokalita nedaleko Čelechovic na Hané $\left(49,5278^{\circ} \mathrm{N} ; 17,0830^{\circ} \mathrm{E}\right)$ byla zvolena s ohledem na vyřešení tohoto problému v místě $\mathrm{s}$ menším sklonem svahu ( $5^{\circ}$ pod stopou zlomu), kde výrazné svahové pohyby s hlubokým dosahem nejsou očekávány. Dvě paralelní rýhy zastihly strmý zlom sz.jv. směru (sklon $70-75^{\circ} \mathrm{k} \mathrm{JZ}$ ), porušující celou sukcesi pod antropogenním sedimentem a pod bází půdního horizontu, který je neporušen (obr. 3 a 4). Charakter sedimentů v hloubce 1-2 m pod bází rýh byl zjištován zaráženými sondami. Zdánlivý vertikální skok na zlomu je 0,6-0,8 m pro svrchní část sukcese a minimálně $4 \mathrm{~m}$ pro spodní část sukcese koluvií. Morfologie zlomu je ve srovnání s rýhou u Stařechovic výrazně jednodušší - hlavní zlom s dominantním posunem je př́mo asociován s doprovodnými protiklonnými zlomy, které porušují pouze pokleslý blok. Charakter zlomů, pozorovaný posun horizontů sedimentů a geofyzikální indikace ukazují na výraznou poklesovou složku pohybu a velmi pravděpodobně významnou horizontální složku, tedy šikmý pokles. Smysl pohybu a velikost obou jeho složek budou nadále studovány. Datování sedimentů není ukončeno - předpokládáme svrchnopleistocenní stáří celé sukcese a stáří nejmladších spraší porušených 


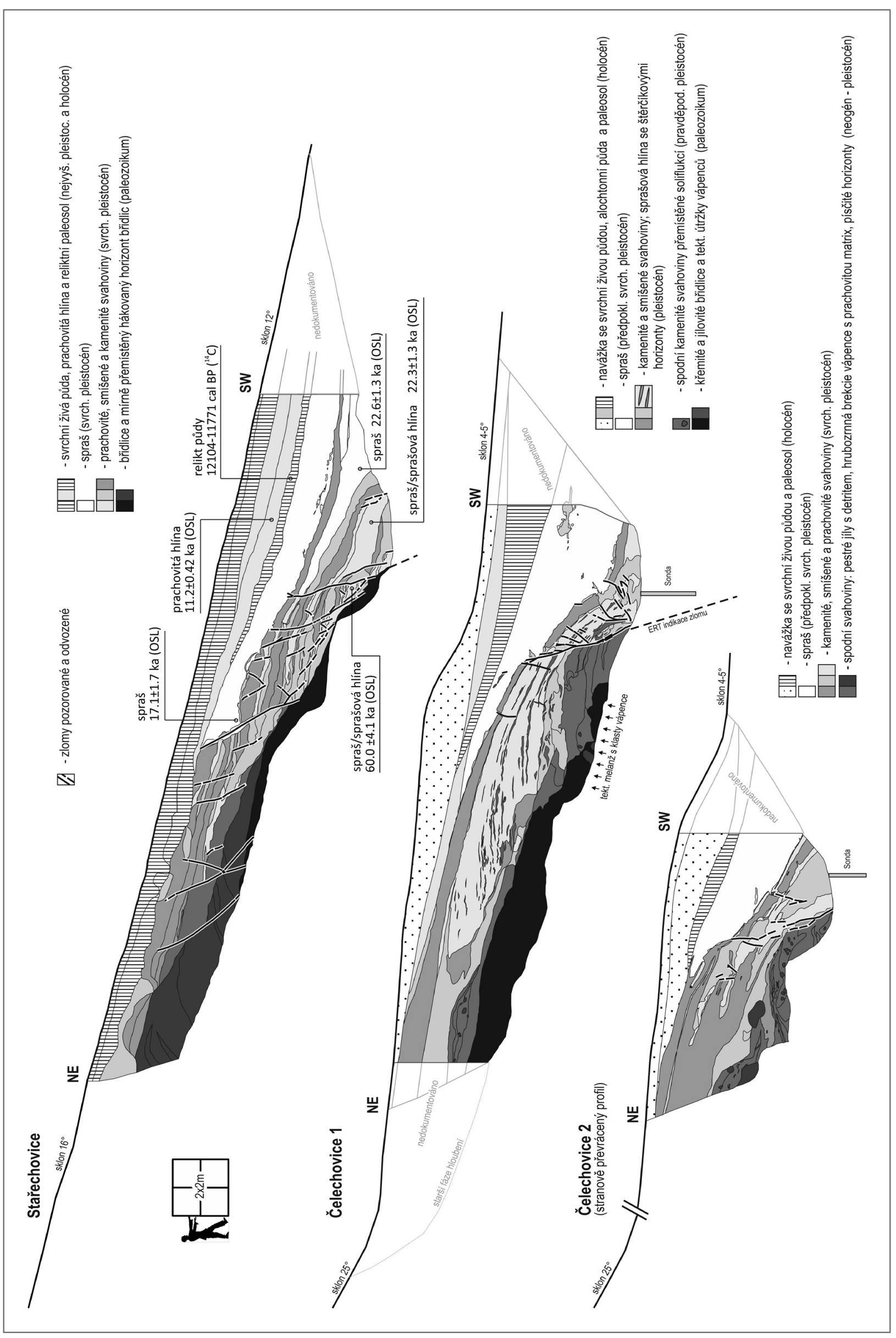




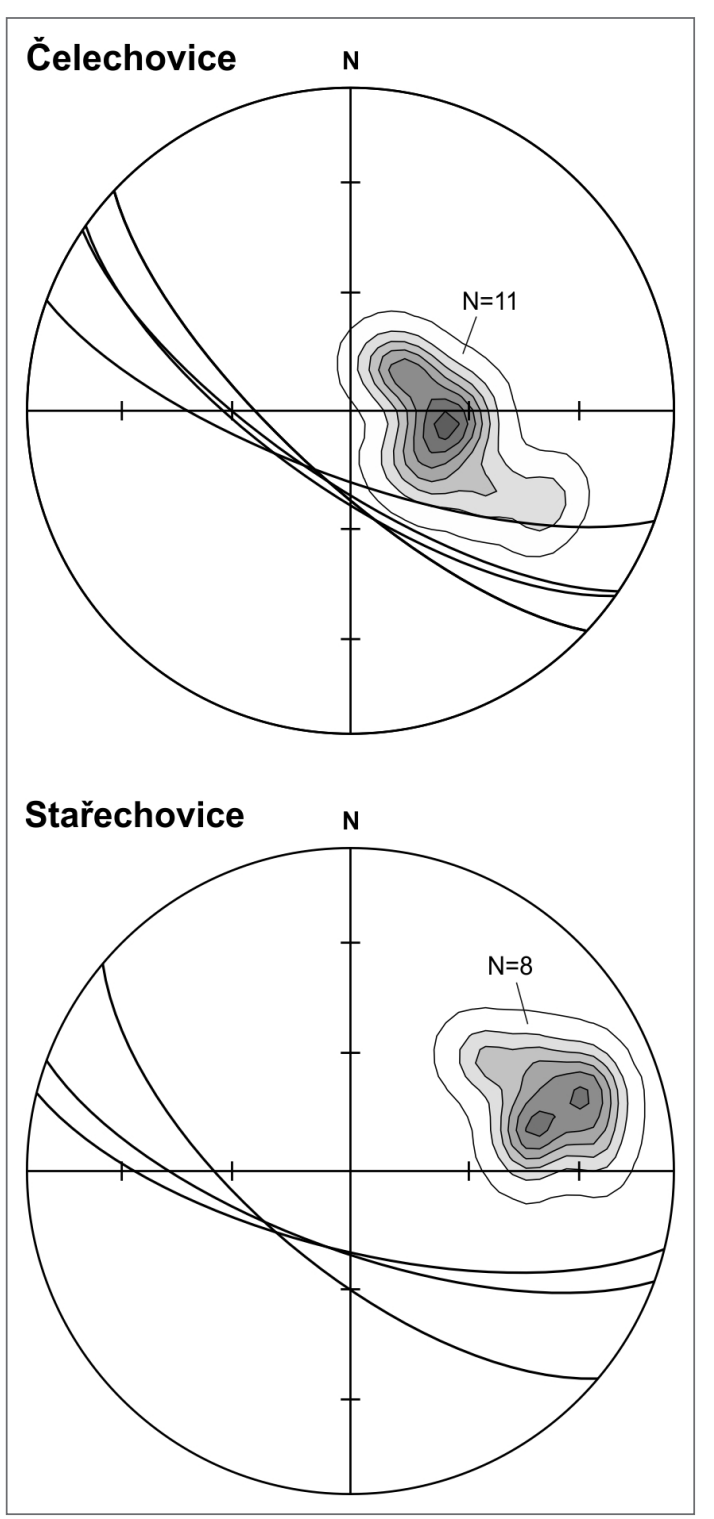

Obr. 4: Orientace zlomů odkrytých v kopaných rýhách (oblouky) a konturové diagramy hustoty pólů vrstevnatosti/kliváže v paleozoických břidlicích a vápencích (v rýhách a v blízkém okolí). Spodní polokoule Lambertovy projekce.

Fig. 4: Orientation of the faults exposed in trenches (great circles) and density contour diagrams of bedding/cleavage poles in paleozoic shales and limestones (in trenches and close neighbourhood). Lower hemisphere of the Lambert projection. zlomem analogické s lokalitou Stařechovice, tj. $<20$ tis. let. Holocenní pohyb na zlomu je kontraindikován neporušeným půdním horizontem.

\section{Závěr}

Přestože datování sedimentů z rýh Čelechovice ještě není dokončeno, na základě obdobného litologického vývoje v obou lokalitách a na základě pozorování minimálních pohybů na zlomech předpokládáme rychlost tektonického pohybu na zlomu v období pozdního pleistocénu $\mathrm{v}$ řádu $0,1-0,3 \mathrm{~mm} / \mathrm{rok}$. Takto prímo indikovaný posun na zlomu je poměrně rychlý a překvapivě mladý. Lze předpokládat, že by dlouhodobější tektonické pohyby této intenzity mohly být doprovázeny viditelnou odezvou ve svrchnopleistocenních fluviálních depozičních systémech HMÚ. Taková odezva však prozatím nikde v HMÚ nebyla jednoznačně prokázána a je tedy možné, že pozorovaný pohyb na zlomu Kosíře reprezentuje pouze krátkou periodu zvýšené aktivity, která kontinuálně nenavazuje na střednopleistocenní pohyby. V současnosti probíhá podobný výzkum na holešovském zlomu poblíž Brodku u Přerova. Jeho výsledky by mohly přispět k úplnějšímu obrazu mladé deformační historie zlomového pásma Hané.

S ohledem na potenciální aktivitu zlomů pásma Hané v současnosti (přestože na zlomu Kosíře byl holocenní pohyb vyloučen) a možný režim deformace formou epizodických pohybů se silnými seismickými jevy s dlouhými opakovacími periodami by struktura HMÚ měla být uvažována ve výpočtu seismického ohrožení.

Podrobné studium profilů kvartérními sedimenty v kopaných rýhách nabízí možnost hlubšího pochopení odezvy specifického sedimentačního prostředí svahů na lokální tektonické a regionální klimatické vlivy. Lze doufat, že srovnání podrobných dat s vysokým rozlišením $\mathrm{Z}$ většího počtu lokalit $\mathrm{v}$ různých pozicích $\mathrm{v}$ budoucnu umožní odlišení těchto vlivů.

\section{Poděkování}

Výzkum v HMÚ je podporován projektem GAČR P210/12/0573 a projektem CzechGeo/EPOS LM2010008. Petr Špaček děkuje J. Krobotovi, P. Táboříkovi, P. Dleštíkovi, J. Valentovi a O. Bábkovi za provedení a podporu geofyzikálních měřenív HMÚ, J. Švábovi, P. Štěpančíkové a J. Stemberkovi za pomoc s pracemi v rýhách, majitelưm a uživatelưm dotčených pozemků (M. Vysloužil; M. Bělejová, SEMO, a. s.; ROLS Lešany, s. r. o.; obec Čelechovice na Hané) za umožnění výkopových prací a rodině K. Sedláčka za jejich technickou realizaci.

Obr. 3: Zjednodušené profily odkryté v kopaných rýhách. Datované jsou prozatím pouze sedimenty rýhy Stařechovice. Radiouhlíkové datum je kalibrované atmosférickou kalibrační křivkou IntCal13 (Reimer et al. 2013) a uvedené s rozsahem $2 \sigma$. Fig. 3: Simplified logs of the trenches Stařechovice, Čelechovice 1 and 2. Only samples from the first trench were dated for the time being. Radiocarbon datum is BP calibrated by IntCal13 curve (Reimer et al. 2013) and given with $2 \sigma$ range. 


\section{Literatura}

Lenhardt, W. - Švancara, J. - Melichar, P. - Pazdírková, J. - Havír, J. - Sýkorová, Z. (2007): Seismic activity of the Alpine-Carpathian-Bohemian Massif region with regard to geological and potential field data. - Geologica Carpathica, 58, 4, 397-412.

Macoun, J. - Růžička, M. (1967): The Quaternary of the Upper Moravian Basin in the relation to the sediments of the continental glaciation. - Sborník geol. věd (Antropozoikum), 4, 125-168.

Reimer, P. J. et al. (2013): IntCal13 and Marine13 radiocarbon age calibration curves 0-50,000 years cal BP. - Radiocarbon 55, 4, 1869-1887.

Růžička, M. (1973): Fluviální sedimenty řeky Moravy v okolí Olomouce. - Sborník geologických věd (Antropozoikum), 9, 7-39.

Špaček, P. - Prachař, I. - Valenta, J. - Štěpančíková, P. - Švancara, J. - Piskač, J. - Pazdírková, J. - Hanžlová, R. - Haviřr, J. - Málek, J. (2011): Quaternary activity of the Hluboká Fault. Final report on research project. 199pp + appendices. - MS ÚFZ MU Brno. Dostupné na: http://www.ipe.muni.cz/hluboka_fault.

Špaček, P. - Bábek, O. - Štěpančíková, P. - Švancara, J. - Pazdírková, J. - Sedláček, J. (2015a): The Nysa-Morava Zone: an active tectonic domain with Late Cenozoic sedimentary grabens in the Western Carpathians' foreland (NE Bohemian Massif). - International Journal of Earth Sciences (Geol Rundsch), 104, 4, 963-990.

Špaček, P. - Ambrož, V. - Tábořík, P. - Štěpančíková, P. (2015b): Digging for records of slow fault slip in the region with strong Pleistocene periglacial mass wasting: experience from the Bohemian Massif (Alpine-Carpathian foreland). - In: Blumetti A. M. et al. (eds.): 6th International INQUA Meeting on Paleoseismology, Active Tectonics and Archaeoseismology, 19-24 April 2015, Pescina, Fucino Basin, Italy Miscellanea INGV 27, 471-474.

Štěpančíková P. - Hók J. - Nývlt D. - Dohnal J. - Sýkorová I. - Stemberk J. (2010): Active tectonics research using trenching technique on the south-eastern section of the Sudetic Marginal Fault (NE Bohemian Massif, central Europe). - Tectonophysics, 485, 269-282.

Štěpančíková, P. - Tábořík, P. - Fischer, T. - Hartvich, F. - Karousová, M. - Stemberk, J. - Nováková, L. (2015): Holocene activity of the Mariánské Lázně Fault (Cheb basin, Bohemian Massif): youngest proved surface faulting in central Europe? - In: Blumetti A.M. et al. (eds.): $6^{\text {th }}$ International INQUA Meeting on Paleoseismology, Active Tectonics and Archaeoseismology, 19-24 April 2015, Pescina, Fucino Basin, Italy Miscellanea INGV, 27, 490-492. 